\title{
Kegiatan Literasi pada Ibu PKK Dusun Bendan Sawangan Magelang dalam Rangka Meningkatkan Penggunaan Obat secara Rasional
}

\author{
Widarika Santi Hapsari $^{1^{*}}$, Fitriana Yuliastuti², Alfian Syarifuddin ${ }^{3}$, Ni Made Ayu Nila \\ Septianingrum ${ }^{4}$ \\ Universitas Muhammadiyah Magelang ${ }^{1,2,3,4}$ \\ widarika@ummgl.ac.id*, fitrianayuliastuti@ummgl.ac.id, alfiansy@ummgl.ac.id, nimadeayunila@ummgl.ac.id
}

\begin{abstract}
Self-medication activities are part of the community's efforts to take care of their health. Gevaarlijk and antibiotics are types of drugs that can only be obtained by prescription from a doctor. Both types of these drugs should not be stored because their use must be under the supervision and has the potential to cause bacterial resistance related to the use of antibiotics. Based on Riskesdas 2013, there are still many people who store gevaarlijk and antibiotics for self-medication. This shows the irrational use of drugs. Community service activities aim to improve knowledge and skills in the use of rational medicine. The method used is the Community-Based Interactive Approach method in which participants play an active role in activities. This participation is important to practice the ability and skill in solving problems. Activities carried out through counseling about the use of rational drugs and antibiotics, then continued with training and assistance for the rational use of drugs and antibiotics. End result of this activity is expected that the community will be able to apply rational drug use and disseminate this information to the wider community.
\end{abstract}

Keywords: Rational drug use; Antibiotic; Community-Based Interactive Approach

\begin{abstract}
Abstrak
Pengobatan sendiri adalah kegiatan pengobatan yang merupakan bagian dari upaya masyarakat untuk menjaga kesehatan mereka sendiri. Obat keras dan antibiotik merupakan jenis obat yang hanya dapat diperoleh dengan resep dokter. Kedua jenis obat ini tidak boleh disimpan karena penggunaannya harus di bawah pengawasan serta berpotensi menimbulkan resistensi bakteri terkait penggunaan antibiotik. Berdasarkan Riskesdas 2013, masih banyak masyarakat yang menyimpan obat keras dan antibiotic untuk pengobatan sendiri. Ini menunjukkan penggunaan obat yang tidak rasional. Kegiatan pengabdian kepada masyarakat ini bertujuan untuk meningkatkan pengetahuan dan keterampilan dalam penggunaan obat secara rasional. Metode yang digunakan adalah metode Community-Based Interactive Approach di mana peserta berperan aktif dalam kegiatan. Partisipasi ini penting untuk melatih kemampuan dan keterampilan dalam memecahkan masalah. Kegiatan dilakukan melalui penyuluhan tentang penggunaan obat rasional dan antibiotik, kemudian dilanjutkan dengan pelatihan dan pendampingan untuk penggunaan obat dan antibiotic secara rasional. Hasil akhir kegiatan ini diharapkan masyarakat mampu menerapkan penggunaan obat secara rasional serta menyebarkan informasi tersebut kepada masyarakat luas.
\end{abstract}

Kata Kunci: Penggunaan obat rasional; Antibiotik; Community-Based Interactive Approach

This is an open access article under the CC-BY SA license 


\section{A. PENDAHULUAN}

Swamedikasi merupakan usaha menyembuhkan penyakit dengan obat tanpa resep dokter (Jain, Sachan, Singla, \& Agrawal, 2014). Swamedikasi atau pengobatan sendiri merupakan kegiatan penggunaan obat tanpa resep dokter atas inisiatif sendiri (FIP, 1998). Pengobatan sendiri hendaknya dilaksanakan dengan pengetahuan yang cukup sehingga dapat menghindari penyalahgunaan, penggunasalahan atau kegagalan terapi dari obat yang digunakan (Antari \& Putra, 2016). Pengetahuan yang cukup akan mempengaruhi tingkah laku seseorang (WHO, 2012). Beberapa studi menunjukkan bahwa peningkatan pengetahuan mempengaruhi keberhasilan swamedikasi diare (Robiyanto dkk., 2018), peningkatan pengetahuan akan meningkatkan perilaku swamedikasi (Pratiwi dkk., 2014), semakin tinggi pengetahuan mengenai antibiotic maka akan makin tinggi sikap untuk tidak menggunakan antibiotik tanpa resep dan rasionalitas penggunaan antibiotik (Gana, 2017).

Sekitar 35,2\% rumah tangga Indonesia menyimpan obat untuk swamedikasi dimana proporsi rumah tangga yang menyimpan obat keras sebesar $35.7 \%$ dan antibiotic sebesar $27,8 \%$. Adanya rumah tangga yang menyimpan antibiotik dan obat keras menunjukkan pengobatan yang tidak rasional (Kementrian Kesehatan RI, 2013). Pelaku swamedikasi berdasarkan jenis kelamin menunjukkan bahwa kegiatan swamedikasi lebih banyak dilakukan oleh perempuan (Gupta et al., 2011).

Waktu penggunaan obat pada masyarakat juga banyak yang belum sesuai dengan aturan. Pada aturan pakai obat 3 kali sehari masih banyak masyarakat yang belum mengetahui bahwa obat diminum dengan selang waktu 8 jam. Begitu juga dengan aturan 2 kali sehari dan seterusnya. Pengelolaan obat di rumah mulai dari penyimpanan hingga pembuaagan obat juga belum sesuai aturan.

Mitra pengabdian masih banyak yang menyimpan obat di rumah. Hal ini yang mendorong dilakukannya kegiatan pengabdian dengan target ibu-ibu PKK. Kegiatan pengabdian dilakukan dengan cara penyuluhan, pelatihan dan pendampingan. Kegiatan pengabdian melalui PKK diharapkan lebih efektif dalam penyebarluasan informasi serta peningkatan keterampilan terkait penggunaan obat rasional. Pemberian edukasi dan peningkatan pengetahuan dapat menurunkan swamedikasi antibiotik (Restiyono, 2016) serta meningkatkan penggunaan obat parasetamol rasional (Hidayati, \& Pristianty, 2017).

Kegiatan ini dilakukan dengan tujuan untuk meningkatkan pengetahuan serta keterampilan dan kemampuan ibu-ibu PKK dalam penggunaan obat dan antibiotik secara rasional. Peserta dari kegiatan ini juga diharapkan mampu menerapkan hasil baik di lingkungan rumah tangga masing-masing maupun lingkungan sekitar.

\section{B. PELAKSAAAN DAN METODE}

Kegiatan pengabdian ini menggunakan metode Cara Belajar Insan Aktif (CBIA). Pada metode ini peserta diikutsertakan dalam kegiatan dimana dilakukan kegiatan pengabdian dan praktek. Kegiatan berlangsung selama 3 bulan.

Kegiatan pendahuluan diawali dengan proses pengajuan ijin kepada pihak terkait. Pada tahap ini juga dilakukan sosialisasi kepada Ketua PKK Dusun Bendan mengenai tujuan dan teknis pelaksanaan kegiatan. Selanjutnya dilakukan perumusan masalah dimana dilakukan juga analisa masalah pada peserta terkait penggunaan obat dan antibiotik. Masalah yang 
diperoleh yaitu kurangnya pengetahuan mengenai obat baik dalam pengenalan obat, penggunaan, penyimpanan obat hingga pembuangan obat.

Pelaksanaan kegiatan dibagi menjadi beberapa tahap. Tahap persiapan yang meliputi koordinasi dengan ketua PKK Dusun Bendan serta ketua RT. Selanjutnya bersama dengan ketua PKK menyusun jadwal kegiatan. Tahap pelaksanaan meliputi sosialisasi program kepada mitra serta kegiatan pemberian materi. Tahap pelatihan dilakukan dengan melatih mitra untuk mengenali obat serta komponennya, penggunaan, penyimpanan dan pembuangan obat. Tahap terakhir yaitu pendampingan dilakukan dengan mendampingi mitra dalam kegiatan pengabdian kepada kader PKK lainnya.

Pada kegiatan dilakukan sosialisasi program dan penyuluhan mengenai penggunaan obat rasional dan antibiotik pada peserta ibu ibu PKK. Kegiatan dilanjutkan dengan pelatihan. Pada tahap ini peserta dibagi menjadi beberapa kelompok dimana masing-masing kelompok terdiri dari 6 peserta. Masingmasing kelompok dibagikan 1 set obat kemudian diminta untuk mengamati komponen obat, menuliskan bahan aktif dan kekuatannya, dan jika kombinasi, mengenali mana bahan utama dan bahan tambahannya, mengelompokkan obat berdasarkan jenis bahan aktif serta mendiskusikan temuan tersebut.

Pada tahap ini masing-masing kelompok mengumpulkan informasi mengenai nama bahan aktif, indikasi, aturan penggunaan, efek samping dan kontraindikasi. Kelompok dipandu oleh tutor. Kegiatan dilanjutkan dimana masing-masing kelompok memaparkan hasil temuan. Tutor merangkum kembali temuan penting dan memberikan pesan untuk menyebarluaskan pengetahuan dan keterampilan memilih obat

Pada kegiatan pendampingan dilakukan dengan meminta peserta untuk mencari informasi mengenai obat-obatan yang terdapat di rumah. Kegiatan dilanjutkan dengan melakukan FGD (Focus Group Discussion) dimana peserta memberikan pemaparan mengenai obat-obatan yang diperoleh di rumah masing-masing. Peserta didampingi oleh pelaksana.

Kegiatan pendampingan juga dilakukan dengan melakukan pendampingan kepada ibuibu PKK dalam menyampaikan informasi mengenai penggunaan obat rasional kepada kader dengan menggunakan buku saku.

\section{HASIL DAN PEMBAHASAN}

Kegiatan dimulai dengan pengajuan ijin kepada Ketua PKK Dusun Bendan. Setelah memperoleh ijin kemudian dilakukan koordinasi dengan pihak pihak terkait untuk melakukan kegiatan.

Keseluruhan kegiatan pengabdian berjalan selama 3 bulan meliputi kegiatan penyuluhan, pelatihan dan pendampingan. Pada awal kegiatan dilakukan analisa situasi peserta terkait pengetahuan peserta mengenai obat dan antibiotik. Diperoleh hasil bahwa rata rata peserta belum mempunyai pengetahuan yang cukup mengenai cara penggunaan obat rasional maupun cara penggunaan antibiotik yang tepat. Kurangnya pengetahuan peserta meliputi penggunaan obat, pemilihan obat, penyimpanan obat serta pembuangan obat. Peserta juga banyak yang tidak memperhatikan waktu kadaluarsa obat. Permasalahan terkait antibiotik meliputi kurangnya pengetahuan mengenai macam antibiotik, cara dan waktu penggunaan, tempat memperoleh antibiotik serta pembuangan antibiotik. Berdasarkan hasil analisa tersebut maka disusun materi pengabdian serta jadwal kegiatan pengabdian. 
Kegiatan dilanjutkan dengan penyuluhan berisi penyampaian materi dan diskusi mengenai penggunaan obat dan antibiotik rasional yang dilaksanakan di awal program. Pemberian materi dilakukan dengan cara tatap muka sehingga dapat terjadi interaksi antara oemateri dengan peserta. Pasien dibekali materi dalam bentuk diktat. Materi penggunaan obat rasional berupa tema $5 \mathrm{O}$ yaitu mengenai nama obat, indikasi obat, dosis obat, cara penggunaan obat dan efek samping obat, penggolongan obat (obat paten, obat generik, obat generik bermerk, obat bebas, obat bebas terbatas, obat keras, obat dalam dan obat luar). Obat digunakan dalam pencegahan dan penyembuhan penyakit sehingga dalam penggunaannya harus digunakan secara hati-hati.

Masing-masing golongan obat mempunyai tanda tersendiri pada kemasan yang menunjukkan penggolongan obat yaitu obat bebas dan obat bebas terbatas yang dapat dibeli tanpa resep dokter, obat keras dan narkotika yang harus dibeli menggunakan resep dokter. Pada kemasan juga tertera nomor ijin edar atau nomor registrasi yang menunjukkan bahwa obat tersebut telah terdaftar pada Badan Pengawas Obat dan Makanan (BPOM) untuk menjamin bahwa obat yang diperoleh aman, berkhasiat dan bermutu. Peserta diberi informasi penggunaan obat harus sesuai dengan indikasi penyakit yang dapat dilihat pada kemasan obat. Pada penggunaan obat dapat muncul efek samping obat merupakan efek yang tidak diinginkan pada penggunaan obat pada dosis lazim seperti mengantuk, gatal, mual dan lain sebagainya. Materi mengenai efek samping obat juga diberikan sehingga pasien mengetahui apa yang harus dilakukan jika dalam mengkonsumsi obat tertentu mengalami efek samping.
Peserta juga diberikan penjelasan mengenai cara dan tempat mendapatkan obat secara legal. Obat sebaiknya dibeli di sarana resmi yaitu apotek, toko obat berizin, klinik dan rumah sakit. Pemberian materi juga diberikan dengan memberikan contoh obat yang dimaksud.

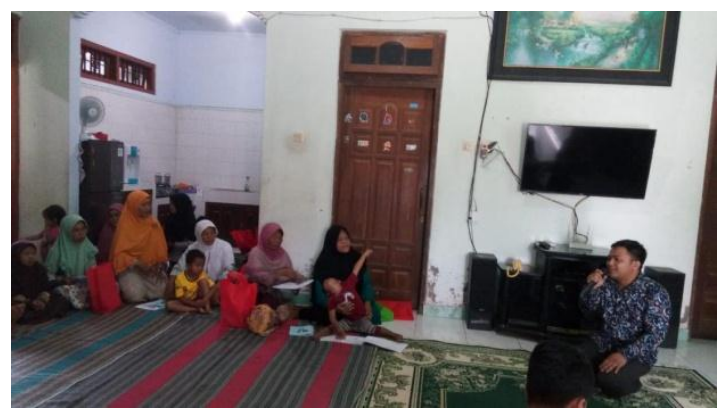

Gambar 1. Kegiatan Penyuluhan Pada Ibu Ibu PKK

Pada aturan pemakaian obat dijelaskan mengenai waktu minum obat. Pada aturan minum 3 kali sehari maka obat dikonsumsi tiap 8 jam, aturan minum 2 kali sehari maka obat dikonsumsi tiap 12 jam dan seterusnya.

Penyuluhan mengenai penggunaan antibiotik rasional berisi materi mengenai macam antibiotik, waktu penggunaan antibiotik. Pemberian informasi mengenai antibiotik penting dilakukan karena makin banyaknya kasus resistensi antibiotik. Pada beberapa kasus ditemukan bahwa masyarakat belum mengetahui mengenai apa fungsi antibiotik serta waktu dan bagaimana cara memperoleh antibiotik. Peserta juga diminta untuk menyebutkan beberapa nama antibiotik yang pernah didengar dan atau dikonsumsi. Dari hasil penelusuran juga diperoleh informasi bahwa masih banyak yang menyimpan antibiotik jika penggunaan sebelumnya tidak habis. Hal ini tidak tepat karena antibiotik harus dihabiskan.

Pada kegiatan ini peserta diberikan penjelasan mengenai kapan antibiotik dapat digunakan, durasi penggunaan serta dimana dapat memperoleh antibiotik yang benar. Antibiotik tidak boleh disimpan di rumah. Antibiotik diberikan jika memang terdapat infeksi bakteri. Ketika pasien merasakan sakit, 
maka dapat diberikan golongan obat bebas atau obat bebas terbatas untuk meredakan gejala penyakit sebagai swamedikasi sementara.

Penyakit seperti diare tanpa disertai lendir atau darah tidak perlu menggunakan antibiotik karena penyebab diare bukan bakteri. Batuk pilek juga tidak memerlukan antibiotik. Jika mengkonsumsi antibiotik maka penggunaannya harus dihabiskan untuk memaksimalkan pengobatan dan menghindari terjadinya resistensi. Antibiotik juga hanya dapat diperoleh dengan resep dokter dan diperoleh di apotek, rumah sakit atau klinik.

Pada pemberian materi mengenai obat diberikan materi mengenai obat rusak, kadaluarsa, cara penyimpanan dan bagaimana cara membuang obat. Penyimpanan dapat mempengaruhi kualitas obat. Berbagai macam bentuk sediaan obat mempunyai cara penyimpanan yang berbeda. Penyimpanan obat seperti tablet, kapsul, sirup, salep dilakukan pada suhu kamar. obat seperti suppositoria yang disimpan pada suhu khusus yaitu $2-8^{\circ} \mathrm{C}$. Cara penyimpanan obat khusus ini umumnya sudah ditulis pada kemasan. Contoh pada penyimpanan suhu $2-8^{\circ} \mathrm{C}$ artinya obat disimpan pada lemari pendingin bukan freezer. Pada suhu $15-30^{\circ} \mathrm{C}$ atau $25-30^{\circ} \mathrm{C}$ obat disimpan pada suhu ruangan biasa. Obat juga disimpan pada tempat yang terlindung dari paparan sinar matahari langsung. Obat disimpan dalam kemasan asli dan dengan etiket yang masih lengkap, jauhkan dari paparan sinar matahari langsung, suhu tinggi, serta jauhkan dari jangkauan anak anak. Pada saat menyimpan diperiksa juga kondisi obat dan waktu kadaluarsa.

Cara penyimpanan obat yang tidak tepat dapat menyebabkan obat lebih cepat rusak walaupun belum kadaluarsa. Maka dalam penyimpanan diperhatikan kondisi penyimpanan, suhu, kelembaban udara. Pada suhu terlalu panas atau terlalu dingin dapat terjadi reaksi kimia sehingga merusak kandungan obat.

Cara pembuangan obat harus dilakukan dengan tepat karena rawan penyalahgunaan oleh pihak yang tidak bertanggungjawab. Obat harus dibuang dengan cara ditimbun di tanah atau dibuang ke saluran air. Kemasan obat dalam bentuk botol sebelum dibuang dilepas dahulu etiket dan tutup botol. Obat dalam bentuk cairan dibuang ke kloset selain antibiotik. Antibiotik dalam bentuk cairan dibuang bersama dengan wadah dimana label sudah dihilangkan ke tempat sampah. Jika obat dalam bentuk boks atau dus atau tube, digunting terlebih dahulu baru dibuang. Obat rusak atau kadaluarsa juga harus segera dibuang.

Pada diskusi dengan peserta, peserta menyatakan tidak memperhatikan waktu kadaluarsa yang tertera pada kemasan obat. Waktu kadaluarsa harus diperhatikan karena menunjukkan jaminan produsen obat terhadap suatu produk. Pada akhir kegiatan dilakukan diskusi mengenai penggunaan baik antibiotik maupun obat lain yang selama ini diketahui dan digunakan peserta. Pada sesi ini dilakukan tanya jawab mengenai permasalahan terkait obat.

Pada kegiatan pelatihan, peserta dikelompokkan menjadi 5 kelompok dimana masing-masing kelompok diberikan sejumlah obat. Kemudian masing-masing kelompok diminta untuk berdiskusi mengenai obat-obatan tersebut.

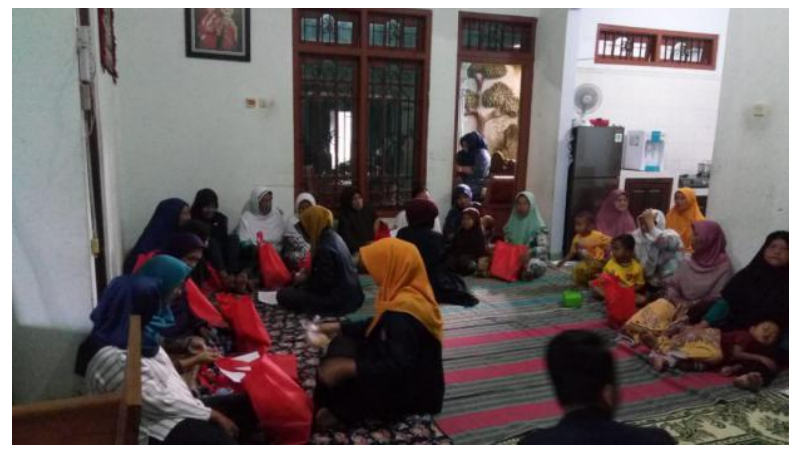

Gambar 2. Kegiatan Diskusi 
Obat-obatan yang diberikan terdiri dari berbagai macam bentuk sediaan dan penggunaan. Kegiatan ini bertujuan untuk memberikan pengetahuan dan keterampilan kepada peserta untuk lebih memahami mengenai penggolongan obat, informasi pada kemasan dan brosur, cara pemilihan dan mendapatkan obat, bentuk sediaan, peringatan dan perhatian, dosis obat, cara penggunaan obat, efek samping obat, cara penyimpanan obat, obat rusak dan kadaluarsa dan cara pembuangan obat.

Diskusi masing-masing kelompok dipandu oleh tutor dan membahas mengenai nama obat (generik dan atau dagang), komposisi, indikasi, dosis dan kontraindikasi dengan cara melihat informasi yang terdapat pada kemasan obat. Pada akhir diskusi masing-masing kelompok memaparkan hasil diskusi melalui lembar diskusi. Diskusi ditutup dengan pengambilan kesimpulan yang berisi temuan temuan masing-masing kelompok.

Kegiatan diskusi ini juga bertujuan untuk memberi keterampilan kepada masyarakat dalam mencari informasi yang terdapat pada kemasan obat, sehingga dalam pelaksanaan swamedikasi masyarakat dapat menggunakan obat secara rasional.

Pada akhir kegiatan pelatihan dilakukan dengan meminta peserta untuk melihat dan mengamati obat-obatan yang terdapat di rumah masing-masing. Pada sesi kegiatan ini selanjutnya peserta diminta untuk memaparkan macam obat yang berada di rumah. Pada tahap ini kegiatan bersifat mandiri (berbeda dengan kegiatan sebelumnya yang bersifat kelompok).

Pada pertemuan selanjutnya peserta diminta untuk memaparkan hasil pengamatan mengenai macam obat yang digunakan di rumah masing-masing. Hasil kegiatan menunjukkan peserta dapat memaparkan poin-poin seperti yang dilakukan pada kegiatan sebelumnya.

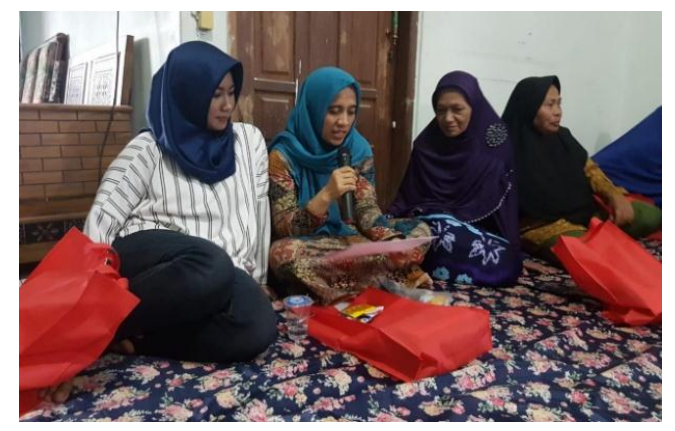

Gambar 3. Peserta menyampaikan hasil diskusi

Kegiatan pendampingan dilakukan pada kegiatan Posyandu lansia dimana pelaksana mendampingi ibu ibu PKK dalam memberikan penyuluhan dan pelatihan kepada kader posyandu. Kegiatan ini dilakukan dengan metode penyuluhan dan pemberian pelatihan seperti kegiatan sebelumnya. Tujuan dari kegiatan pendampingan ini adalah untuk meningkatkan pengetahuan dan keterampilan masyarakat yang lebih luas melalui ibu ibu PKK yang sudah mendapat penyuluhan dan pelatihan.

\section{PENUTUP}

\section{Simpulan}

Kegiatan pengabdian di Dusun Bendan Sawangan Kabupaten Magelang dengan peserta ibu ibu PKK berjalan dengan baik dan lancar. Adanya kegiatan ini pengetahuan dan keterampilan ibu ibu PKK meningkat dalam pengelolaan obat, penggunaan obat rasional, penggunaan antibiotic secara rasional

\section{Saran}

Kegiatan pengabdian sebaiknya diberikan secara berkala dan menjangkau masyarakat yang lebih luas. Materi juga dapat diperluas seperti pemberian materi mengenai terapi herbal 
sebagai alternatif terapi swamedikasi yang aman.

\section{Ucapan Terima Kasih}

Penulis mengucapkan terimakasih kepada Lembaga Penelitian Pengembangan dan Pengabdian Kepada Masyarakat Universitas Muhammadiyah Magelang atas dukungan dana terhadap kegiatan pengabdian tersebut.

\section{E. DAFTAR PUSTAKA}

Antari, N. P. U., \& Putra, Ag. S. 2016. Tingkat Pengetahuan Tentang Penanganan Obat Dalam Swamedikasi Dan Pengaruhnya Terhadap Kebiasaan Menggunakan Obat Pada Responden Di Apotek Gunung Sari, 2(2), 53-56.

Hidayati, I. R., \& Pristianty, L. 2017. Pengaruh Pengetahuan Terhadap Penggunaan Obat Parasetamol Yang Rasional dalam Swamedikasi (Studi pada Ibu Rumah Tangga di desa Sumberpoh Kecamatan Maron Kabupaten Probolinggo). Jurnal Farmasi Dan Ilmu Kefarmasian Indonesia, 4(2), 44-50.

FIP, I. P. F. 1998. Responsible SelfMedication. FIP Council

Gana, T. 2017. Hubungan Pengetahuan Tentang Antibiotik Dengan Sikap dan Tindakan Penggunaan Antibiotik Tanpa Resep Di Kalangan Mahasiswa Ilmu Kesehatan Universitas Respati Yogyakarta.

Gupta, P., Bobhate, P. S., \& Shrivastava, S. R. 2011. Asian Journal of Pharmaceutical and Clinical Research, 4(3), 3-6.
Jain, P., Sachan, A., Singla, R. K., \& Agrawal, P. 2014. Statistical Study on Self Medication Pattern in Haryana, India Statistical Study on Self Medication Pattern in Haryana, India. Indo Global Journal of Pharmaceutical Sciene.

Kementrian Kesehatan RI. 2013. Riset Kesehatan Dasar. Badan Penelitian dan Pengembangan Kesehatan Kementerian Kesehatan RI.

Pratiwi, P. N., Pristianty, L., Noorrizka, G., \& Impian, A. 2014. Pengaruh Pengetahuan Terhadap Perilaku Swamedikasi Obat AntiInflamasi Non-Steroid Oral Pada Etnis Thionghoa Di Surabaya. Jurnal Farmasi Komunitas, 1(2), 36-40.

Restiyono, A. 2016. Analisis Faktor yang Berpengaruh dalam Swamedikasi Antibiotik pada Ibu Rumah Tangga di Kelurahan Kajen Kebupaten Pekalongan. Jurnal Promosi Kesehatan Indonesia, 11(1).

Robiyanto, Rosmimi, M., \& Untari, E. K. 2018. Analisis Pengaruh Tingkat Pengetahuan Masyarakat Terhadap Tindakan Swamedikasi Diare Akut Di Kecamatan Pontianak Timur. Edukasi: Jurnal Pendidikan, 16(1).

WHO. 2012. The Pursuit of Responsible Use of Medicines: Sharing and Learning from Country Experiences. 